\title{
Characterization of Highper, an ENU-induced mouse mutant with abnormal psychostimulant and stress responses
}

\author{
Amy F. Eisener-Dorman • Janice S. Bailey • \\ Laura Grabowski-Boase • Salvador Huitron-Resendiz • \\ Amanda J. Roberts • Tim Wiltshire • Lisa M. Tarantino
}

Received: 21 February 2012 /Accepted: 24 July 2012 / Published online: 5 September 2012

(C) The Author(s) 2012. This article is published with open access at Springerlink.com

\begin{abstract}
Rationale Chemical mutagenesis in the mouse is a forward genetics approach that introduces random mutations into the genome, thereby providing an opportunity to annotate gene function and characterize phenotypes that have not been previously linked to a given gene.

Objectives We report on the behavioral characterization of Highper, an $N$-ethyl- $N$-nitrosourea (ENU)-induced mutant mouse line.

Methods Highper and B6 control mice were assessed for locomotor activity in the open field and home cage environments. Basal and acute restraint stress-induced corticosterone
\end{abstract}

Electronic supplementary material The online version of this article (doi:10.1007/s00213-012-2827-5) contains supplementary material, which is available to authorized users.

A. F. Eisener-Dorman · J. S. Bailey · L. M. Tarantino $(\bowtie)$

Department of Psychiatry, University of North Carolina,

Chapel Hill, NC 27599, USA

e-mail: lisat@med.unc.edu

L. Grabowski-Boase

Genomics Institute of the Novartis Research Foundation,

San Diego, CA, USA

S. Huitron-Resendiz $\cdot$ A. J. Roberts

Molecular and Integrative Neurosciences Department,

The Scripps Research Institute,

La Jolla, CA, USA

\section{T. Wiltshire}

Institute of Pharmacogenomics and Individualized Therapy, Division of Pharmacotherapy and Experimental Therapeutics, University of North Carolina,

Chapel Hill, NC, USA

Present Address:

J. S. Bailey

Department of Biological Sciences, Miracosta College,

Oceanside, CA, USA levels were measured. Mice were tested for locomotor response to cocaine $(5,20,30$, and $45 \mathrm{mg} / \mathrm{kg}$ ), methylphenidate (30 mg/ $\mathrm{kg})$, and ethanol $(0.75,1.25$, and $1.75 \mathrm{~g} / \mathrm{kg})$. The rewarding and reinforcing effects of cocaine were assessed using conditioned place preference and self-administration paradigms.

Results Highper mice are hyperactive during behavioral tests but show normal home cage locomotor behavior. Highper mice also exhibit a twofold increase in locomotor response to cocaine, methylphenidate, and ethanol and prolonged activation of the hypothalamic-pituitary-adrenal axis in response to acute stress. Highper mice are more sensitive to the rewarding and reinforcing effects of cocaine, although place preference in Highper mice appears to be significantly influenced by the environment in which the drug is administered.

Conclusions Altogether, our findings indicate that Highper mice may provide important insights into the genetic, molecular, and biological mechanisms underlying stress and the drug reward pathway.

Keywords ENU $\cdot$ Mutagenesis $\cdot$ Behavior $\cdot$ Cocaine $\cdot$ Activity $\cdot$ CPP $\cdot$ Self-administration $\cdot$ Alcohol .

Methylphenidate $\cdot$ HPA

\section{Introduction}

Addiction is a significant public health concern with serious personal, economic, and societal impacts. Family and twin studies indicate that susceptibility to drug addiction is heritable (Bierut et al. 1998), and a genetic basis for drug abuse and drug response has been established in studies of human populations (Uhl et al. 1995) and in animal models (Crabbe et al. 1994; George and Goldberg 1989; Seale and Carney 1991). Consequently, the identification of genes that contribute to drug abuse susceptibility has become a priority of psychopharmacological research. 
Due to the complex etiology of addiction and the inherent difficulties of conducting such studies in human populations, the genetic factors predisposing individuals to addiction remain largely unknown. While animal models do not replicate the full spectrum of the human drug abuse syndrome, they have been used successfully to model druginduced behavioral responses. Inbred mouse strains show extensive phenotypic variability for many drug-induced behaviors (Ruiz-Durantez et al. 2006; Seale and Carney 1991), and various techniques have been used to identify genetic differences that account for phenotypic variation (Boyle and Gill 2001; Bryant et al. 2012; Crabbe et al. 1999; Downing et al. 2006). However, these studies often result in the identification of large genomic regions containing hundreds of potential candidate genes, and identifying the causative genetic lesion has been difficult.

The chemical mutagen $N$-ethyl- $N$-nitrosourea (ENU) was first used in mice to induce heritable point mutations in the 1970s. In the 1990s, ENU mutagenesis experienced a resurgence as a method for assigning gene function and generating new mouse models for complex traits. ENU mutagenesis is a high-throughput approach for generating random heritable mutations in an unbiased manner, thereby allowing for the identification of phenotypes that have not yet been linked to a given gene. ENU-induced mutations have resulted in the identification of genes underlying complex phenotypes, including ataxia (Sharkey et al. 2009; Swanson et al. 2010; Xie et al. 2010), epilepsy (Frankel et al. 2009; Tokuda et al. 2011), and deafness (Grillet et al. 2009; Mackenzie et al. 2009; Parker et al. 2010; Schwander et al. 2009a, b). Mapping ENU-induced mutations for complex behavioral phenotypes has proven particularly difficult, but genes involved in locomotor activity have been identified (Furuse et al. 2010; Keays et al. 2004; Speca et al. 2010).

Here, we report the characterization of an ENU-induced mutant, Highper, that was discovered in a behavioral screen for open-field behavior. Highper mice exhibit noveltyinduced hyperactivity, exaggerated locomotor response to psychostimulants, and increased sensitivity to the rewarding and reinforcing effects of cocaine. Highper mice also demonstrate a prolonged elevation of plasma corticosterone levels following acute restraint stress, indicating that Highper mice could model a link between stress and behavioral responses to psychostimulant drugs.

\section{Materials and methods}

\section{Animals}

C57BL/6J (B6) mice from the Jackson Laboratory (Bar Harbor, ME, USA) were bred at the in-house breeding colony at the Genomics Institute of the Novartis Research
Foundation (GNF) and the University of North Carolina at Chapel Hill (UNC). Mice were maintained in an AAALACaccredited, specific pathogen-free barrier colony in ventilated cages (Thoren Caging Systems (GNF), Hazelton, PA, USA or Tecniplast (UNC), Italy) on a 12-h light-dark cycle (lights on at 6:00 A.M. (GNF), 7:00 A.M. (UNC)). Mice were housed in groups of two to five in cages containing bedding (Bed-o-cob) and a cotton nestlet (GNF and UNC) or a PVC tube (UNC only). Irradiated food (Purina Pico rodent chow 20 (GNF) or Purina RMH 3000 (UNC), Purina, St. Louis, MO, USA) and water were provided ad libitum. Experimentally naïve mice were 59-70 days old at onset of testing. Due to shared animal room lighting constraints, behavioral tests were administered during the light part of the light/dark cycle (between 8:00 A.M. and 12:00 P.M.) except when otherwise noted. Locomotor behavior was tested in both light and dark cycles in a subset of mice to determine if Highper locomotor activity was dependent on time of day. All procedures were approved by the GNF, UNC, and Scripps Research Institute Institutional Animal Care and Use Committees following guidelines set forth by the National Institutes of Health (NIH) Guide for the Care and Use of Laboratory Animals.

ENU mutagenesis and identification of the Highper mutant

ENU mutant mice were generated as previously described (Reijmers et al. 2006). Briefly, mutagenized $\mathrm{G}_{0}$ males were mated to $B 6$ females, and $G_{1}$ males were mated to B6 females. $G_{2}$ daughters were mated to their $G_{1}$ fathers to recover recessive mutations in $G_{3}$ males that were screened for behavioral phenotypes. Outliers were \pm 2 standard deviations (SD) from the mean of the last $200 \mathrm{G}_{3}$ mice screened.

$\mathrm{A}_{3}$ outlier ( $>3 \mathrm{SD}$ ) from pedigree 262 was mated to a B6 female to establish the Highper line, and 70 F2s were open-field tested to determine heritability. F2s crossed to B6 mice produced F2N1s that were used to determine the mode of inheritance. Thereafter, the line was maintained by breeding presumed homozygotes.

\section{Drugs}

Cocaine $\mathrm{HCl}$ (Sigma-Aldrich, St. Louis, MO) and methylphenidate $\mathrm{HCl}$ (MPD; Sigma-Aldrich, St. Louis, MO) were dissolved in $0.9 \%$ saline. Based on the literature (Cunningham et al. 1999; Seale and Carney 1991) and data from our laboratory, $20 \mathrm{mg} / \mathrm{kg}$ cocaine induces moderate locomotor response in B6 and was used for initial locomotor activation studies. Multiple doses of cocaine $(5,20,30$, and $45 \mathrm{mg} / \mathrm{kg})$ were used to assess dose response and self-administration $(0.13$, $0.25,0.5$, and $1.0 \mathrm{mg} / \mathrm{kg}$ ). MPD was administered at $30 \mathrm{mg} /$ $\mathrm{kg}$. Ethanol was administered as a $20 \%(v / v)$ solution at 0.75 , 1.25 , or $1.75 \mathrm{~g} / \mathrm{kg}$. 
Open-field behavior

The open-field apparatus (ENV-515-16, Med Associates, St. Albans, VT, USA) was a $43.2 \times 43.2 \times 33-\mathrm{cm}$ arena consisting of a white Plexiglas floor and clear Plexiglas walls with infrared detection beams at 1-in. intervals on the $x, y$, and $z$ axes that tracked the animals' position and activity automatically throughout the experimental session. The apparatus was in a sound-attenuating chamber fitted with two overhead light fixtures containing $28-\mathrm{V}$ lamps. Mice were moved to an anteroom for at least $1 \mathrm{~h}$ prior to testing, and animals were removed from their home cage, placed in the corner of the open-field arena, and allowed to freely explore the apparatus. Total distance traveled (centimeters) in the open-field arena was recorded in 2-5-min bins and scored in post-session analyses using commercially available software (Activity Monitor 5.1, Med Associates). Other measures of locomotor and exploratory behavior, including rearing, ambulatory episodes, and average velocity, were also assessed. The testing apparatus was cleaned with a $0.1 \%$ bleach solution between test subjects.

\section{Locomotor response and habituation}

Basal locomotor activity was recorded in a 10-min openfield session. To assess intersession and intrasession habituation effects on activity, mice were tested in one 10-min session for three consecutive days, and activity within and across days was analyzed.

\section{Circadian effects on locomotor activity}

Locomotor activity in the open field was assessed in Highper (38 female and 19 male) and B6 (32 female and 29 male) mice in 10-min sessions during either the light (8:00 A.M. and 12:00 P.M.) or dark (8:00 P.M. and 12:00 A.M.) phase.

\section{Home cage activity}

Home cage locomotor activity of Highper (11 females and 6 males) and B6 (eight females and six males) mice was assessed for $17 \mathrm{~h}$ (3:45 P.M.-8:45 A.M.). Mice were individually housed for 1 week prior to testing. On the day of testing, the entire mouse cage was placed into the openfield arena, and locomotor activity was recorded in 10-min bins. The sum of activity in the light phase $(3: 45-6: 00$ P.M., 6:00-8:45 A.M.) and the dark phase (6:00 P.M.-6:00 A.M.) was calculated. The effects of phase (light or dark), strain, and sex on locomotor activity were examined by ANOVA.
Locomotor response to cocaine

To assess cocaine-induced acute locomotor response in a novel environment, naïve Highper (six male and ten female) and B6 (eight female and seven male) mice received an injection of $20 \mathrm{mg} / \mathrm{kg}$ cocaine or saline immediately prior to being placed in the open field for a 180-min session. The sum of the total distance traveled was calculated, and cocaineinduced activity was normalized to baseline activity by subtracting the within-strain average distance for saline-treated mice from individual distances for cocaine-treated mice.

Cocaine-induced locomotor activity was also measured in Highper (17 female and 14 male) and B6 (21 female and 19 male) mice after 3 days (intersession) and $3 \mathrm{~h}$ (intrasession) of habituation in the open field. On days 1-3, animals were given a sham saline injection and placed in the open-field arena for $10 \mathrm{~min}$ and then returned to their home cages. On day 4, animals were placed in the open-field arena for $60 \mathrm{~min}$, given an injection of saline, and immediately returned to the arena for $120 \mathrm{~min}$. The animals then received an injection of either saline or $20 \mathrm{mg} / \mathrm{kg}$ cocaine and were returned to the arena for $180 \mathrm{~min}$.

Locomotor response to methylphenidate

Highper (nine male and seven female) and B6 (11 male and 15 female) mice that had previously been tested in the open field for cocaine-induced locomotor behavior were tested 11-12 days later for locomotor response to $30 \mathrm{mg} / \mathrm{kg}$ MPD or saline. Mice were randomly assigned to receive either MPD or saline with regard to previous cocaine treatment so that treated and control groups were a mixture of mice that had received both cocaine and saline. The locomotor activity of mutant and control mice was assessed in a single 360 min open-field session, as described above. Total distance traveled during the 180-min interval following drug administration was calculated for each animal and normalized to baseline activity for each strain by subtracting the withinstrain average distance for saline-treated mice from individual distances for MPD-treated mice.

Alcohol-induced locomotor response and coordination

Alcohol-induced locomotor activity was assessed in Highper (40 male and 41 female) and B6 (83 male and 68 female) mice. On days 1-3, mice were injected with IP saline, and on day 4 , mice received a $20 \%(v / v)$ ethanol solution $(0.75,1.25$, or $1.75 \mathrm{~g} / \mathrm{kg})$ or saline. Immediately following injection, mice were placed in the open field for $30 \mathrm{~min}$. Distance over the test session was collected, and difference scores (day 4-day 3) were calculated. Immediately following each open-field session, animals were placed on the rotarod apparatus (Ugo Basile, Collegeville, 
PA, USA) for one trial. Revolutions per min (rpm) started at $3 \mathrm{rpm}$ and progressively increased to $30 \mathrm{rpm}$ during the 5min trial. Latency to fall and latency to the first passive rotation were recorded. Animals that did not fall during the trial were assigned the maximum latency of $300 \mathrm{~s}$. Rotarod performance was calculated as both the latency to fall and the latency to first passive rotation on day 4 (alcohol) as compared to day 3 .

\section{Acute restraint and HPA activity}

Highper (seven female and eight male) and B6 (seven female and seven male) mice were tested for restraint stress-induced hypothalamic-pituitary-adrenal (HPA) activation. Animals were restrained for $10 \mathrm{~min}$ in a Broome-style restrainer (Plas Labs, Inc., Lansing, MI, USA). Retro-orbital bleeds were performed immediately prior to restraint and 30 and $120 \mathrm{~min}$ post-restraint. Whole blood was centrifuged to isolate plasma, and corticosterone (CORT) levels were analyzed by competitive radioimmunoassay as per the manufacturer's protocol (MP Biomedicals, Santa Ana, CA, USA). CORT was also measured during open-field testing. After $180 \mathrm{~min}$ in the arena, animals were given cocaine and returned for $180 \mathrm{~min}$. Retro-orbital bleeds were performed on separate groups at 5 and $180 \mathrm{~min}$ (pre-cocaine) and 215 and $300 \mathrm{~min}$ (post-cocaine).

\section{Conditioned place preference}

The rewarding properties of cocaine were tested in Highper ( 26 male and 23 female) and B6 (22 male and 19 female) mice using a three-chambered apparatus (MED-CPP-MSAT, Med Associates) as described in Eisener-Dorman et al. (2011). Briefly, mice were habituated on day 1, and time spent in either the black or white compartment was determined. Mice were randomly assigned to receive cocaine in either the black or white compartment (32 Highper and 30 B6). In a follow-up study, all mice received cocaine in the white compartment (17 Highper and 11 B6). On days 2, 4, 6, and 8, animals were given saline before placement in the unpaired compartment. On days 3, 5, 7, and 9, mice were given cocaine before placement in the drug-paired compartment. On day 10, mice could move freely between compartments, and percent time in the drug-paired compartment was compared to preconditioning. Activity on day 3 vs. day 2 was assessed as acute locomotor response, and activity on day 9 vs. day 3 was assessed as cocaine-induced locomotor sensitization.

Cocaine self-administration

Cocaine self-administration testing was performed during the dark phase of the light/dark cycle. Male and female Highper and wild-type mice were catheterized using chronic jugular catheters (Pañeda et al. 2009) and trained to self- administer cocaine $\mathrm{HCl}(0.5 \mathrm{mg} / \mathrm{kg}, 15 \mathrm{~mL}$ infusion $)$ in daily 1-h sessions using a fixed ratio (FR 1) schedule of reinforcement. A total of 32 Highper (16 male and 16 female) and 31 wild-type B6 (16 male and 15 male) successfully met self-administration criteria ( $>10$ infusions per session, $70 \%$ or more pressing on active lever, and variation of pressing on active lever less than $25 \%$ across three consecutive days). These mice also had patent catheters, as verified by administering $0.02 \mathrm{ml}$ of sodium brevital $(5 \mathrm{mg} /$ ml; Monarch Pharmaceuticals, Bristol, TN) 24-48 h after surgery and again at the completion of cocaine selfadministration (i.e., prior to extinction sessions). Cocaine doses $(0.125,0.25,0.5$, and $1.0 \mathrm{mg} / \mathrm{kg} /$ infusion) were tested in daily 1-h sessions in a randomized order with the acquisition dose tested between each test dose. Dose effect curves were generated for each mouse strain. A subset of four to five mice per sex per genotype was subjected to progressive ratio (PR) testing. The $\mathrm{PR}$ procedure involved increasing the number of responses required to obtain a reinforcer until the animal failed to respond for $30 \mathrm{~min}$. The last ratio completed was defined as the "breaking point." The ratio progression followed the equation: [5e (injection number $\times 0.20$ )] -5 (rounded to the nearest integer), such that the sequence of lever press requirements would begin: 1, 2, 4, 6, 9, 12, 15, $20,25,32,40,50,62,77$, etc. Several doses $(0.13,0.25,0.5$, and $1.0 \mathrm{mg} / \mathrm{kg}$ ) were tested with intervening FR 1 sessions. In the other 11-12 mice per sex per genotype the cocaine was removed and replaced with saline (i.e., the conditions of these trails were identical to the standard self-administration trials except that saline was substituted for cocaine), and lever pressing (i.e., extinction behavior) was determined over 10 days.

\section{Optomotor testing}

Visual function was assessed in Highper (14 male and eight female) and B6 (eight male and nine female) mice using the optomotor assay (see Supplementary methods).

Light/dark assay

Highper (14 male, eight female) and B6 (eight male, nine female) mice were tested for anxiety-like behavior in the light/dark assay (Crawley 1999) (see Supplementary methods).

Spontaneous alternations (Y-maze)

Spontaneous alternation behavior, which measures spatial working memory, exploratory behavior, and response to novelty, was tested in Highper (14 male and 8 female) and B6 (eight male and nine female) mice (see Supplementary methods). 
Fear conditioning

Highper (6 male and 13 female) and B6 (6 male and 11 female) mice were tested for fear responses in the fearconditioning assay (Med Associates, St. Albans, VT, USA) (see Supplementary methods).

\section{Statistical analyses}

Data were analyzed using the SPSS statistical package (version 16.0 for Macintosh, SPSS, Chicago, IL, USA). Analysis of variance (ANOVA) tests were performed to analyze the effects of strain, sex, time point, treatment, and/or drug dose on the dependent variable. Dependent variables included total distance, activity difference score, CORT levels, percent time, movements, lever press count, and percent freezing. Mean differences were significant at $p<0.05$. Error bars indicate SEM.

\section{Results}

The Highper mutation is recessive with reduced penetrance

Twenty-six $G_{3}$ males from $G_{1}$ pedigree 262 were tested in the open field, and two $\mathrm{G}_{3}$ outliers exhibited activity $>3$ SD from the mean of the last 200 mice screened (Fig. 1a). One of the male outliers was crossed to a B6 female, and open-field behavior was tested in $70 \mathrm{~F} 2 \mathrm{~s}$. Eleven out of $70 \mathrm{~F} 2 \mathrm{~s}$ (14\%) exceeded an activity threshold defined as $>2$ standard deviations higher than the mean of a group of contemporaneously tested B6 mice, thereby confirming heritability. Mode of inheritance was tested by crossing affected F2s to B6 and testing 48 F2N1s. The Highper F2N1 population was not significantly different from 50 contemporaneously tested B6 mice (Fig. 1b); therefore, the Highper mutation did not fit a dominant mode of inheritance. The line was maintained by crossing presumed homozygotes, and activity was significantly elevated for all subsequent generations compared to contemporaneous controls (Fig. 1c). Based on the number of affected animals per generation (F3-F8) and the F2N1 data, the Highper mutation is recessive with reduced penetrance (Table 1).

\section{Highper mice are not hyperactive in the home cage}

Home cage activity was analyzed to determine if the Highper phenotype was due to basal locomotor differences. An ANOVA for home cage activity showed a significant effect of phase $\left(F_{(1,61)}=16.8 ; p<0.001\right)$ but no strain, sex, or interaction effects. All mice had increased activity during the dark phase, but no strain differences were observed indicating that Highper mice are not hyperactive in the home cage (Fig. 1d).
Highper locomotor behavior is not light phase-dependent

To determine if the hyperactive phenotype of Highper mice was influenced by the time of day mice were tested, we measured open-field behavior in Highper during light and dark phases. A phase effect was observed $\left(F_{(1,117)}=8.6\right.$; $p<$ $0.01)$ indicating that all mice showed significantly higher activity during the dark phase. Strain $\left(F_{(1,117)}=67.5 ; p<\right.$ $0.001)$ and sex effects $\left(F_{(1,117)}=22.9 ; p<0.001\right)$ were also observed. Highper mice exhibited increased activity compared to B6. A sex by strain interaction $\left(F_{(1,117)}=6.8 ; p<\right.$ $0.05)$ was observed, and post hoc analysis indicated that Highper females exhibited higher activity than Highper males $(t(55)=-4.0 ; p<0.001)$. The sex difference was also significant in controls $(t(59)=-2.3 ; p<0.05)$. No strain by phase interaction was detected; therefore, time of day during testing did not alter strain activity differences (data not shown).

Highper mice habituate to the open field

To examine whether the Highper phenotype was due to the novelty of the arena, we evaluated the effect of intersession habituation on locomotor activity in the open field in Highper (54 females and 42 males) and B6 (63 females and 57 males) mice over three consecutive days. ANOVA indicated strain $\left(F_{(1,215)}=90.3 ; p<0.001\right)$, sex $\left(F_{(1,215)}=10.3 ; p<0.01\right)$, and day effects $\left(F_{(2,215)}=26.5 ; p<0.001\right)$. Females were more active than males, and Highper mice were more active than B6 for all 3 days. All mice were significantly less active on days 2 and 3 compared to day 1 (Supplementary Fig. 1). No interaction effects were observed; all mice habituated with repeated exposure, but Highper activity never diminished to B6 levels. A similar pattern was observed for other measures in the open field, including rearing $\left(F_{(2,215)}=20.9 ; p<0.001\right)$, ambulatory episodes $\left(F_{(2,215)}=45.3 ; p<0.001\right)$, and average velocity $\left(F_{(2,215)}=16.4 ; p<0.001\right.$; data not shown).

Highper mice exhibit increased locomotor response to cocaine

Test-naïve Highper mice were assessed for locomotor response to an acute cocaine dose. Highper mice showed a greater cocaine-induced locomotor response compared to B6, but this difference was not significant after subtracting mean baseline activity (saline) from cocaine-induced activity for each animal. No significant strain $\left(F_{(1,15)}=0.37 ; p>0.05\right)$, $\operatorname{sex}\left(F_{(1,15)}=0.33 ; p>0.05\right)$, or strain by sex interaction effects $\left(F_{(1,15)}=0.00 ; p>0.05\right)$ were detected (Supplementary Fig. 2).

To mitigate the effects of high baseline activity in Highper mice, we established a protocol for 3 days (intersession) and $3 \mathrm{~h}$ (intrasession) of habituation prior to cocaine administration. Post-habituation, all mice exhibited similar activity immediately preceding cocaine administration $\left(F_{(1,37)}=3.9\right.$; $p>0.05)$. We examined total activity for the $180 \mathrm{~min}$ post- 
Fig. 1 Highper mice are hyperactive in the open field. a Two G3 outliers (circled) from the same pedigree were identified as affected mutants. b Comparison of B6 wild-type and Highper F1 mice generated by crossing an affected $\mathrm{F} 2$ back to B6 to determine mode of inheritance. c Open-field data from presumed homozygous Highper mice at the F2-F8 generations and $\mathrm{B} 6$ controls show that the Highper mutation is likely a recessive mutation with approximately $50 \%$ penetrance. Solid and broken lines represent the mean and two SD from the mean, respectively. $\mathbf{d}$ Highper mice do not exhibit hyperactivity in the home cage environment in either the dark or the light part of the circadian cycle. Error bars are SEM
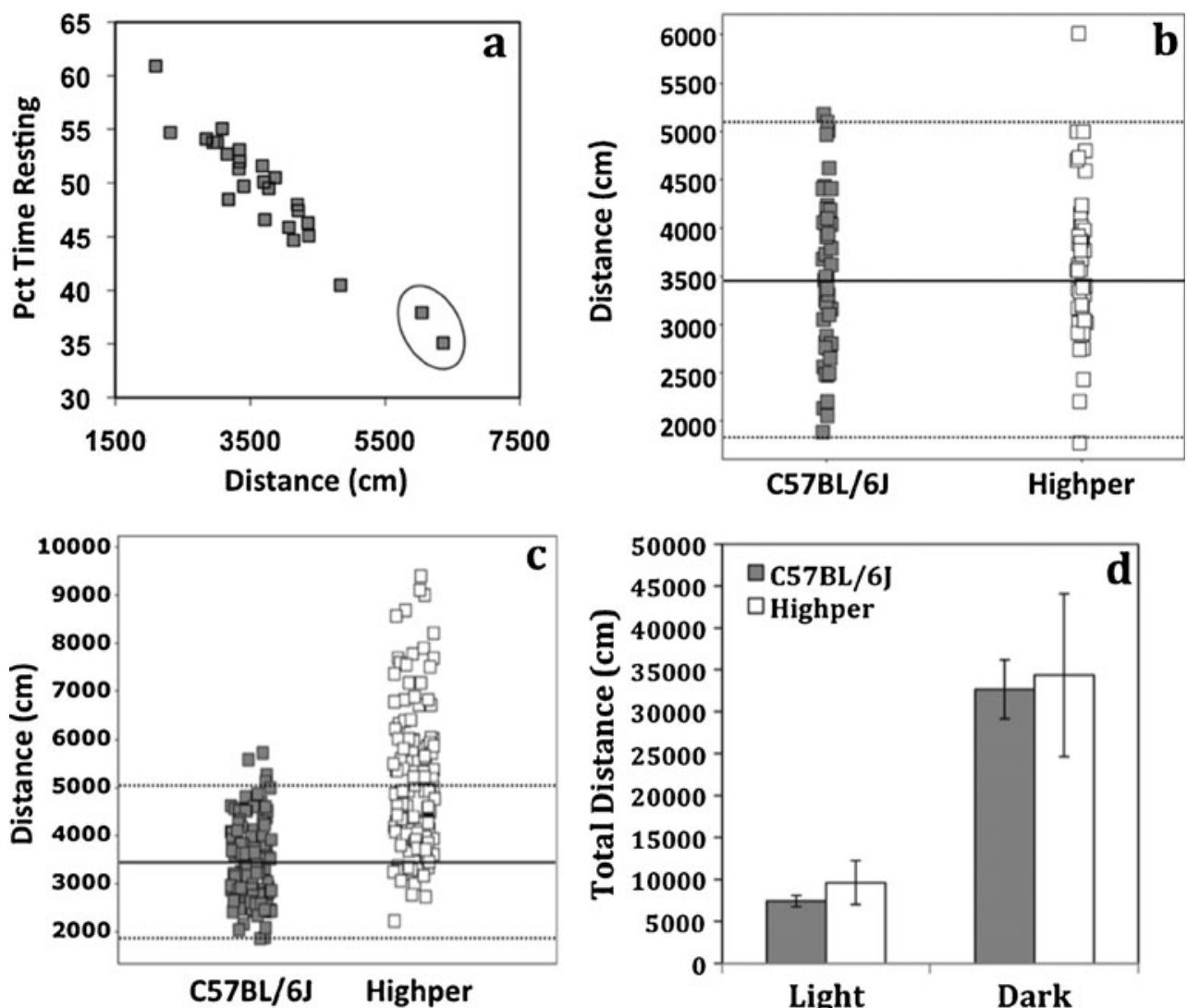

cocaine administration, normalized for saline-induced activity and identified a strain effect $\left(F_{(1,37)}=19.3 ; p<0.001\right)$. When cocaine was administered after habituation, Highper mice showed a significantly higher locomotor response (Fig. 2a). No sex $\left(F_{(1,37)}=2.3 ; p>0.05\right)$ or sex by strain interaction effects $\left(F_{(1,37)}=1.6 ; p>0.05\right)$ were detected. Highper mice also make more ambulatory episodes in comparison to B6 following cocaine administration $\left(F_{(1,71)}=5.3\right.$; $p<0.05)$. The same difference was not observed for either rearing behavior $\left(F_{(1,71)}=0.21 ; p>0.05\right)$ or average velocity $\left(F_{(1,71)}=0.18 ; p>0.05\right.$; Supplementary Fig. 3$)$.

Cocaine dose response was also assessed in Highper and B6 controls. Cocaine-induced locomotor activity (normalized to saline-treated controls) was analyzed by ANOVA, and strain $\left(F_{(1,65)}=10.48 ; p<0.01\right)$ and dose $\left(F_{(3,65)}=7.06 ; p\right.$ $<0.001)$, but no strain by dose interaction effects $\left(F_{(3,65)}=\right.$
$0.99 ; p>0.05)$ were detected. Cocaine-induced locomotor response was greater in Highper than in B6 mice at 20 and $30 \mathrm{mg} / \mathrm{kg}$ but not at $5\left(F_{(1,15)}=1.9 ; p>0.05\right)$ or $45 \mathrm{mg} / \mathrm{kg}$ doses $\left(F_{(1,15)}=0.36 ; p>0.05\right.$; Fig. 2b). No sex differences were observed $\left(F_{(1,65)}=0.57 ; p>0.05\right)$.

Drug-induced hyperactivity in Highper mice is not cocainespecific

We tested Highper mice for sensitivity to MPD. Because the mice were previously treated with a single dose of cocaine or saline to assess cocaine-induced locomotor activation, we tested the effect of previous treatment on MPD response. No previous treatment effect on MPD response was observed $\left(F_{(1,41)}=0.1 ; p>0.05\right)$ nor were any interaction effects observed between prior cocaine exposure and

Table 1 The Highper ENU mutant hyperactivity phenotype exhibits a recessive inheritance pattern with incomplete penetrance

\begin{tabular}{llcccc}
\hline Generation & Genotype (inferred) & Number tested & Expected number affected & Actual number affected & Penetrance (\%) \\
\hline G3 & Mixed & 26 & 3 & 2 & 66 \\
F2 & Mixed & 70 & 18 & 11 & 61 \\
F2N1 & Heterozygous & 48 & 0 & 3 & NA \\
F3N1 & Mixed & 70 & 17 & 61 & 59 \\
F3-F8 & Heterozygous & 127 & 127 & 48 \\
\hline
\end{tabular}

Affected animals were identified by open-field activity scores $>2$ SD from the mean 
Fig. 2 Habituation alters openfield locomotor response to an acute dose of $20 \mathrm{mg} / \mathrm{kg}$ cocaine in Highper mice. a Cocaineinduced psychomotor response is significantly greater in Highper mice when the drug is administered following habituation to the open-field arena. b Dose response to four doses of cocaine in Highper and B6 mice. Cocaine-induced locomotion was normalized to saline-induced locomotion to correct for baseline activity differences. Error bars are SEM. ${ }^{*} p<0.05$
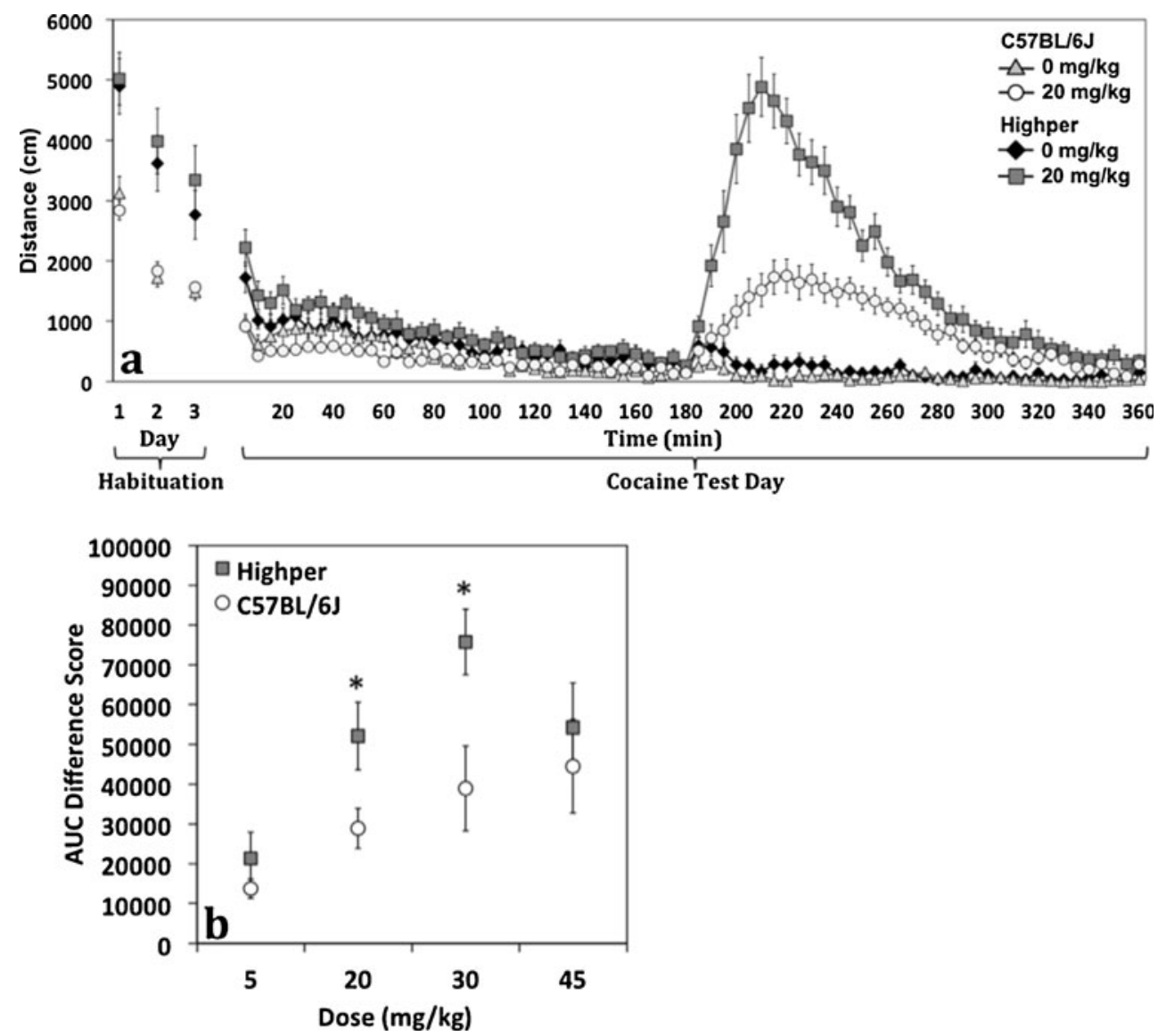

strain $\left(F_{(1,41)}=0.91 ; p>0.05\right)$ or prior exposure, strain, cocaine exposure did not affect MPD response. Strain and MPD dose $\left(\mathrm{F}_{(1,41)}=0.98 ; p>0.05\right)$. Therefore, prior $\quad\left(F_{(1,41)}=15.0 ; p<0.01\right)$ and dose effects $\left(F_{(1,41)}=138.5\right.$;

Fig. 3 Highper mice exhibit increased context-specific place preference and acute locomotor response to $20 \mathrm{mg} / \mathrm{kg}$ cocaine. a Acute locomotor response was determined by comparing activity in the conditioned place preference apparatus on day 3 (first cocaine treatment) and day 2 (saline). b Cocaine was administered either in the black or white CPP chamber. Place preference was significantly higher in Highper mice when cocaine was paired with the white chamber but not the black chamber. c Locomotor activity was higher in the black chamber of the place preference apparatus during habituation (day 1) and conditioning (days 2-9). Chamber-specific activity differences were present in both saline- and cocainetreated animals. Error bars are SEM. ${ }^{*} p<0.05, * * p<0.01$, and $* * * p<0.001$
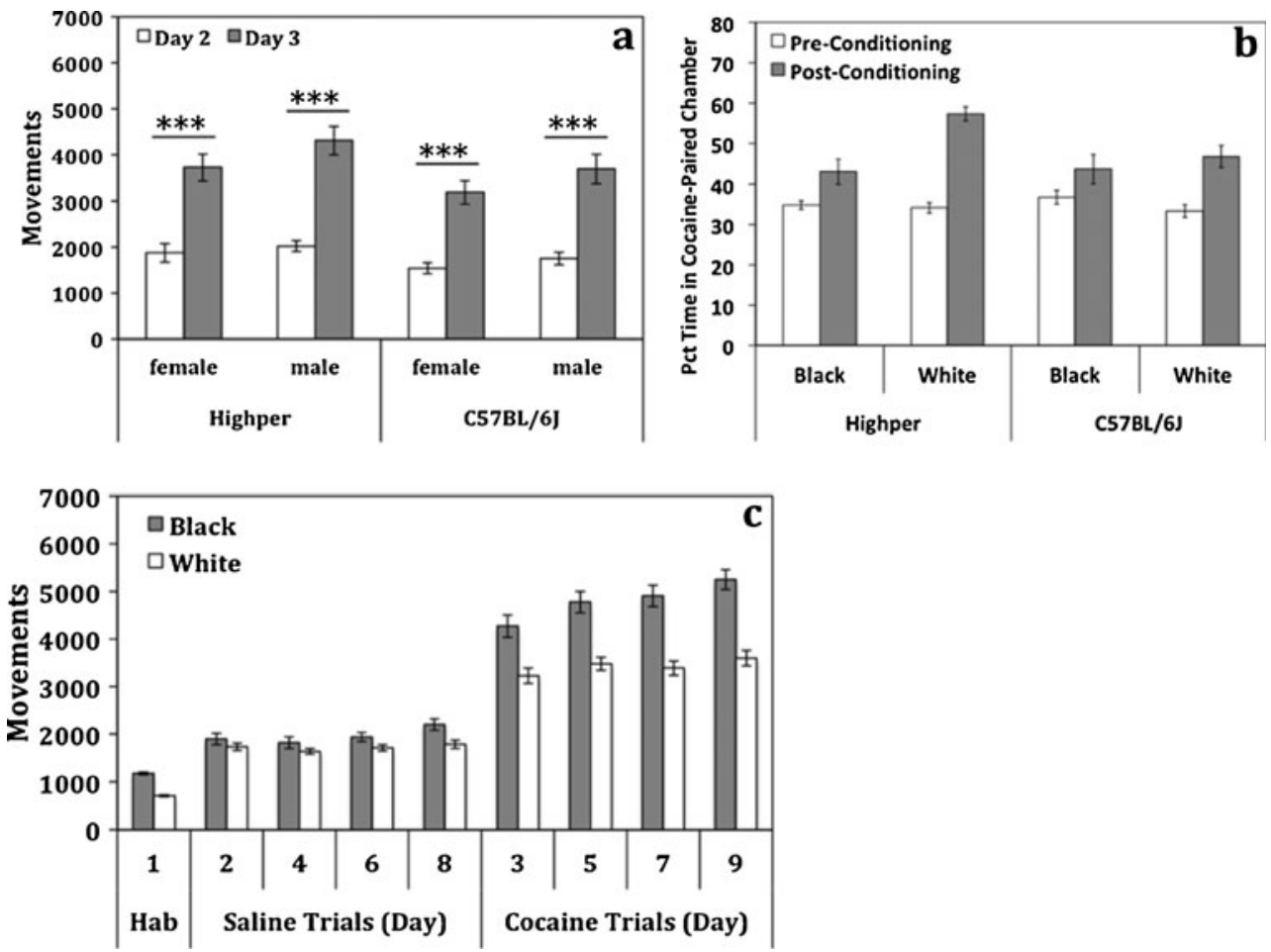
$p<0.001)$ and a strain by dose interaction $\left(F_{(1,41)}=9.8\right.$; $p<0.01)$ were observed. All mice showed MPD-induced locomotor activation, but the Highper activity was significantly higher than B6 activity (Supplementary Fig. 4).

We tested the Highper locomotor response to ethanol. Dose $\left(F_{(3,231)}=9.1 ; p<0.001\right)$, strain $\left(F_{(1,231)}=32.6 ; p<\right.$ $0.001)$, and strain by dose interaction effects were observed $\left(F_{(3,231)}=3.4 ; p<0.05\right)$. Post hoc analysis indicated that Highper mice showed higher locomotor responses to the $0.75(p<0.01)$ and $1.25 \mathrm{~g} / \mathrm{kg}(p<0.001)$ doses but not to the $1.75 \mathrm{~g} / \mathrm{kg}$ dose (Supplementary Fig. 5). No sex differences were observed $\left(F_{(1,231)}=3.4 ; p>0.05\right)$.

Locomotor coordination on the rotarod following exposure to the same doses of alcohol was also assessed in Highper and B6 mice. ANOVA of latency to fall from rotarod (difference scores) showed a dose effect $\left(F_{(3,199)}=\right.$ $10.91 ; p<0.001)$. Post hoc analysis showed a significant difference in response to $1.25(p<0.01)$ and $1.75 \mathrm{~g} / \mathrm{kg}(p<$ $0.001)$ compared to saline and between 0.75 and $1.25 \mathrm{~g} / \mathrm{kg}$ $(p<0.05)$ and 0.75 and $1.75 \mathrm{~g} / \mathrm{kg}(p<0.001)$. No sex $\left(F_{(1,199)}=1.55 ; p>0.05\right)$, strain $\left(F_{(1,199)}=1.23 ; p>0.05\right)$, sex by strain $\left(F_{(1,199)}=0.27 ; p>0.05\right)$, sex by dose $\left(F_{(3,199)}=\right.$ $1.78 ; p>0.05)$, or strain by dose interaction effects $\left(F_{(3,199)}=0.30 ; p>0.05\right)$ were identified (data not shown).

\section{Highper mice exhibit greater cocaine-induced CPP}

Mice spent a similar amount of time in the black and white chambers on day 1 indicating that the conditioned place preference $(\mathrm{CPP})$ apparatus was unbiased $(t(178)=0.87 ; p>$ 0.05 , data not shown). However, ten animals (six Highper, four B6) spent significantly more time in the black or white chamber ( $>3$ or $<3$ SD from group mean) and were removed from CPP analysis. Day 1 activity differed by strain $\left(F_{(1,173)}=\right.$ 15.7; $p<0.001)$; Highper mice were more active than B6.

All mice showed increased activity after the first cocaine treatment $\left(F_{(1,178)}=209.2 ; p<0.001\right)$, but cocaine-induced locomotor activation was higher in Highper mice (Fig. 3a). Activity was significantly greater on day 9 , after the final cocaine treatment, than on day $3(p<0.01)$ in both Highper and B6 mice. However, this difference was dependent on the chamber in which cocaine was administered $(p<0.001)$. When each chamber was considered separately, sensitization occurred only in the black chamber $(p<0.05)$ and only in B6 mice $(p<0.05)$ (Supplementary Fig. 6).

ANOVA indicated that conditioning chamber affected CPP development $\left(F_{(1,55)}=7.3 ; p<0.01\right)$; mice conditioned in the white chamber showed significantly higher CPP. In a followup study, mice were conditioned in the white chamber only, and Highper mice had significantly higher $\mathrm{CPP}\left(F_{(1,23)}=6.9\right.$; $p<0.05$; Fig. 3b). All mice exhibited significantly higher activity in the black chamber compared to the white chamber $\left(F_{(1,173)}=176.1 ; p<0.001\right)$. This activity difference persisted throughout saline $\left(F_{(1,244)}=16.6 ; p<0.001\right)$ and cocaine conditioning $\left(F_{(1,247)}=96.7 ; p<0.001 ;\right.$ Fig. $\left.3 c\right)$.

Highper mice show increased responding for lower doses of cocaine

Analysis of the number of cocaine rewards obtained during dose response for the self-administration study identified sex $\left(F_{(1,59)}=4.5 ; p<0.05\right)$, dose $\left(F_{(3,177)}=16.9 ; p<0.001\right)$, strain $\left(F_{(1,59)}=14.1 ; p<0.001\right)$, and strain by dose interaction $\left(F_{(3,177)}=4.1 ; p<0.01\right)$ effects. All mice showed decreased number of rewards as dose increased, and males administered more rewards than females. Highper mice administered more rewards at the two lowest doses (Fig. 4a). This result was not due to general activity differences because Highper mice responded more on the active lever $\left(F_{(1,59)}=7.5 ; \mathrm{c} p<0.01\right)$ than the inactive lever $\left(F_{(1,59)}=\right.$ $0.4 ; c p>0.05$; Supplementary Fig. 7). A subset of mice was used to examine the motivation of Highper mice using a PR schedule. There were no significant strain effects on progressive ratio breakpoints. Highper females had higher breakpoints than their B6 counterparts $\left(F_{(1,7)}=4.5 ; p<\right.$ 0.05 ), which was not observed in males (Fig. $4 \mathrm{~b}, \mathrm{c}$ ). All mice showed lever pressing extinction $\left(F_{(9,351)}=25.5 ; p<\right.$ $0.0001)$, but there was no overall strain difference. A strain by sex interaction $\left(F_{(1,39)}=4.6 ; p<0.05\right)$ revealed that Highper males had higher lever responding than their B6 counterparts $\left(F_{(1,21)}=5.9 ; p<0.05\right.$; Fig. $\left.4 d\right)$.

Highper mice show prolonged stress-induced HPA activation

Previous studies identified a correlation between locomotor response to novelty and prolonged HPA stress reactivity (Piazza et al. 1991). We tested acute restraint stress in Highper mice and identified strain $\left(F_{(1,85)}=12.1 ; p<0.01\right)$, sex $\left(F_{(1,85)}=25.0 ; p<0.001\right)$, and time effects $\left(F_{(2,85)}=55.3 ; p<\right.$ $0.001)$ and a strain by time interaction $\left(F_{(1,85)}=5.5 ; p<0.01\right)$. CORT levels were higher in females and in Highper mice. In both strains, CORT increased significantly from 0 to $30 \mathrm{~min}$ post-restraint. At $120 \mathrm{~min}$, CORT levels remained elevated in Highper mice but decreased to basal levels in B6 (Fig. 5a, b).

The abnormal cocaine-induced locomotor response exhibited by Highper mice is not related to CORT levels during open-field testing

To determine if the abnormal drug-induced locomotor response exhibited by Highper mice is related to prolonged HPA activation, cocaine was administered prior to open-field testing, and CORT levels were assessed at four different timepoints. No strain effect was observed indicating that CORT release during open-field testing was similar for all mice. However, females had higher CORT levels $\left(F_{(1,91)}=40.8\right.$; 
Fig. 4 Highper mice are sensitive to the rewarding effects of cocaine. a Highper mice self-administered more cocaine at the lower doses $(0.125,0.25$, and $0.5 \mathrm{mg} / \mathrm{kg} /$ inf). b, c Female, but not male, Highper mice worked harder for cocaine in a progressive ratio schedule of selfadministration. d All mice show extinction of cocaine-seeking behavior across ten sessions, whereas Highper males had higher levels of responding relative to B6 males. Error bars are SEM
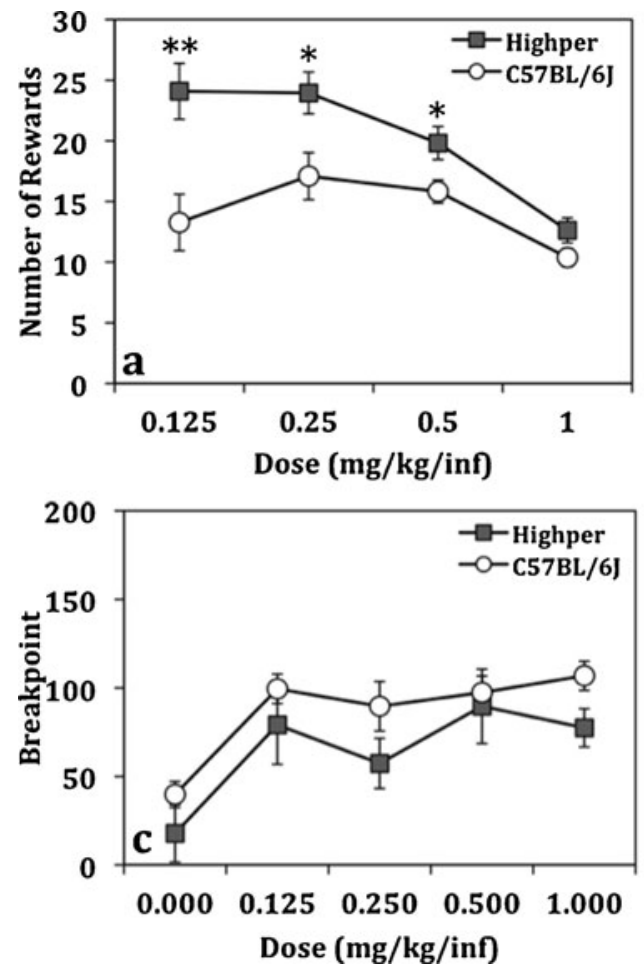
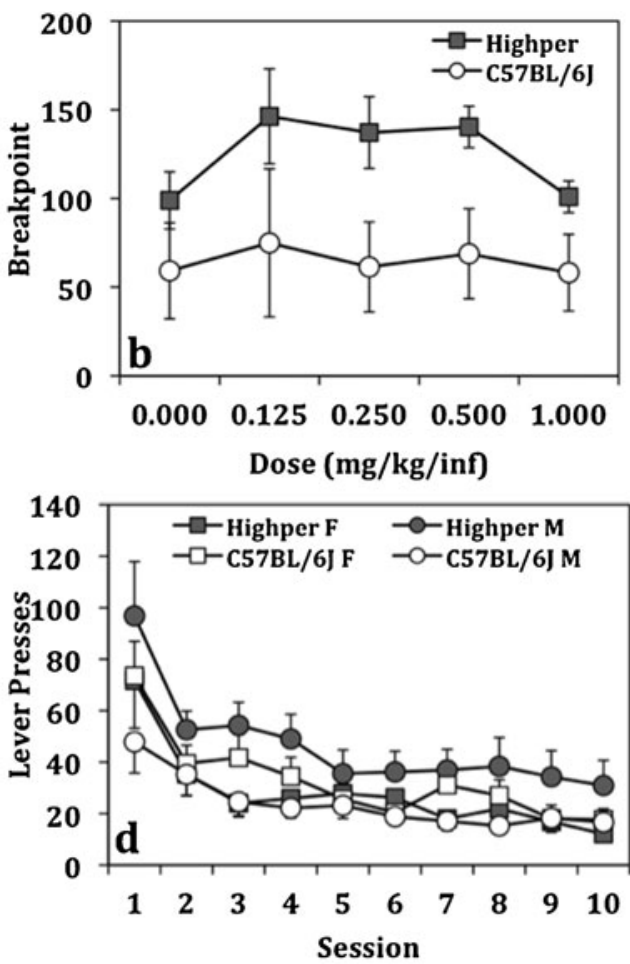

$p<0.001$ ). CORT levels were similar at 5 and $180 \mathrm{~min}$ (precocaine; $p>0.05$ ) but increased significantly at 215 and $330 \mathrm{~min}$ (post-cocaine; $p<0.001$ ). This effect was more prominent in females $\left(F_{(3,46)}=43.0 ; p<0.001\right)$ than in males $\left(F_{(3,46)}=6.2 ; p<0.01\right.$; Supplementary Fig. 8$)$.

\section{Highper mice do not exhibit anxiety-like behavior}

We tested Highper mice in the light/dark task to evaluate anxiety-like behavior. An ANOVA of the amount of time spent in the light side showed no strain $\left(F_{(1,38)}=3.24 ; p>\right.$ $0.05)$, sex $\left(F_{(1,38)}=0.01 ; p>0.05\right)$, or strain by sex interaction effects $\left(F_{(1,38)}=0.91 ; p>0.05\right)$ suggesting that

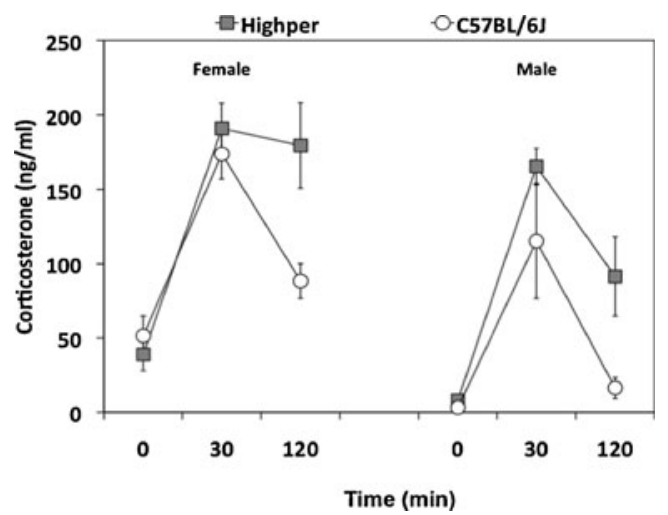

Fig. 5 Highper mice have prolonged HPA activation in response to restraint-induced stress. Corticosterone levels (nanograms per milliliter) were assessed at baseline and 30- and 120-min post-restraint for female (a) and male mice (b). Error bars are SEM. ${ }^{*} p<0.05$
Highper mice do not differ for anxiety-like behavior in comparison to B6 (data not shown). Highper mice exhibited increased light/dark transitions $\left(F_{(1,38)}=25.1\right.$; $p<0.001)$ that is likely due to their novelty-induced hyperactivity phenotype (Supplementary Fig. 9).

Highper mice do not exhibit visual deficits

Optomotor testing was performed to identify visual tracking deficiencies. ANOVA analysis showed no strain $\left(F_{(1,38)}=3.0 ; p>0.05\right)$, sex $\left(F_{(1,38)}=0 ; p>0.05\right)$, or strain by sex interaction effects $\left(F_{(1,38)}=0.64 ; p>0.05\right)$ indicating that Highper mice have no obvious visual impairments (Supplementary Fig. 10).

Highper mice show no deficits in spontaneous alternation

Spontaneous alternations were measured to assess spatial memory, exploratory behavior, and response to novelty in Highper mice. An ANOVA for the number of arm entries in the Y-maze revealed a strain effect $\left(F_{(1,38)}=42.1 ; p<0.001\right)$ but no sex effect $\left(F_{(1,38)}=2.46 ; p>0.05\right)$ and no strain by sex interaction $\left(F_{(1,38)}=3.4 ; p>0.05\right)$ indicating that Highper mice exhibited increased exploratory behavior (data not shown). An ANOVA for the percent of spontaneous alternation observed showed no strain $\left(F_{(1,38)}=0.6 ; p>0.05\right)$, sex $\left(F_{(1,38)}=0.90 ; p>0.05\right)$, or strain by sex interaction effects $\left(F_{(1,38)}=1.24 ; p>0.05\right)$, which suggests that spatial working memory is similar for Highper and B6 mice (Supplementary Fig. 11). 
Highper mice show decreased freezing behavior in the fear conditioning assay

For day 1 baseline freezing, a strain effect $\left(F_{(1,35)}=10.0 ; p<\right.$ $0.01)$ but no sex $\left(F_{(1,35)}=2.0 ; p>0.05\right)$ or strain by sex interaction effects $\left(F_{(1,35)}=0.20 ; p>0.05\right)$ were observed prior to tone-shock training. Highper mice froze significantly less than B6.

Freezing during the day 1 intertrial interval after each tone-shock pairing was analyzed by ANOVA; significant strain $\left(F_{(1,179)}=51.9 ; p<0.001\right)$, sex $\left(F_{(1,179)}=4.0 ; p<0.05\right)$, and interval effects $\left(F_{(3,179)}=6.2 ; p<0.01\right)$ were observed. Females froze more than males, and Highper mice froze significantly less than B6. Freezing increased significantly across intervals with each successive tone-shock pairing. On day 2, Highper mice froze less during the first $3 \mathrm{~min}$ of the session $\left(F_{(1,35)}=4.2 ; p<0.05\right)$. Analysis of freezing during intertrial intervals on day 2 yielded results similar to day 1 ; strain $\left(F_{(1,143)}=17.3 ; p<0.001\right)$, sex $\left(F_{(1,143)}=5.4 ; p<\right.$ $0.05)$, and trial effects $\left(F_{(3,143)}=5.4 ; p<0.01\right)$ were observed. As on day 1, Highper mice froze significantly less than B6, and females froze significantly more than males. Freezing at the last intertrial interval was significantly higher than freezing at the first intertrial interval indicating that fear learning had occurred. Freezing after day 2 conditioning was higher than after day $1(t(70)=-2.7 ; p<0.01)$. This effect did not differ between strains, but overall the strains differed in freezing at the end of both days.

Our test of cued fear memory revealed no significant difference between day 3 baseline freezing in the new context and day 1 baseline freezing $\left(F_{(1,70)}=1.8 ; p>0.05\right)$; thus, animals did not show generalized freezing. No significant strain $\left(F_{(1,70)}=1.5 ; p>0.05\right)$ or sex effects $\left(F_{(1,70)}=4.1 ; p>0.05\right)$ were observed for day 3 baseline freezing. All mice exhibited increased freezing to tones on day $3\left(F_{(2,104)}=12.0 ; p<0.001\right)$. Freezing increased in response to tone $1(p<0.001)$ and tone 2 $(p<0.001)$ relative to baseline freezing, but freezing did not differ between the two tones (Supplementary Fig. 12).

\section{Discussion}

The Highper mutant displays hyperactivity in novel environments, exaggerated locomotor response to psychostimulants, increased sensitivity to the rewarding properties of cocaine, and prolonged stress-induced HPA activation. The absence of sensory and learning and memory deficits removes these potential confounds from the interpretation of our results. Based on the convergence of drug response, reward and reinforcement differences, as well as alterations in HPA reactivity, we propose that Highper mice may be useful for studying the intersection between drug reward and stress response pathways.
The increased locomotor activity in Highper mice appears to be novelty-specific because home cage activity did not differ between mutant and wild-type mice. However, Highper mice were more active than controls in the open field over multiple testing days; thus, Highper mice may exhibit general hyperactivity in test environments. We tested the hypothesis that response to novelty was due to differences in stress response, like those induced by acute restraint; however, CORT levels did not differ between Highper and B6 mice during open-field testing. Differing HPA response to diverse stressors (e.g., open field vs. restraint) is not surprising and has been reported elsewhere (Bowers et al. 2008).

Increased locomotor response to novelty, as observed in Highper mice, correlates with increased psychomotor effects of cocaine in mice (Brabant et al. 2005) and for a variety of psychostimulants in high-responder (HR) and low-responder rats (Belin et al. 2011; Kiyatkin 1992; Deroche et al. 1993; Piazza et al. 1989, 1990). The extent to which novelty-induced locomotor activity behavior translates to more active models of drug seeking or drug taking (i.e., CPP or CSA) has been debated. Whereas some studies have identified a correlation between locomotor response to novelty and drug self-administration (Piazza et al. 1989, 1990; Thomsen and Caine 2011), others have not (Gong et al. 1996; Kosten et al. 2007). In addition, correlations between novelty-induced activity and CPP are often not observed (Erb and Parker 1994; Gong et al. 1996), but these varying results could be due to dose effects because several studies in mice using lower doses of cocaine $(4-5 \mathrm{mg} / \mathrm{kg})$ have reported a significant negative correlation (Brabant et al. 2005; Shimosato and Watanabe 2003).

Other studies have reported an inverse correlation between locomotor activity and CPP (Gremel and Cunningham 2007; Cunningham et al. 1999; Vezina and Stewart 1987; Neisewander et al. 1990; Sora et al. 2001). It has been suggested that high activity levels may interfere with the subject's ability to effectively process its surroundings, thereby reducing associative learning and resulting in decreased CPP. Significantly greater CPP was observed in Highper mice given cocaine in the white compartment in which cocaine-induced locomotor activation was significantly decreased. We theorize that the reduced activity engendered by the white environment caused more robust expression of CPP in the Highper mutant, allowing us to observe true strain differences. This theory is supported by our observation that Highper mice show a more robust response to the psychomotor effects of cocaine after intrasession habituation to the arena that reduces basal activity to wild-type levels. Thus, the overall hyperactivity of Highper mice in novel and/or testing situations may mask the stimulatory and rewarding effects of psychostimulants.

B6 and Highper mice show sensitization upon repeated cocaine administration but only in mice trained in the black 
compartment, indicating that suppression of activity in the white compartment may also alter sensitization. Increased locomotor response follows the second cocaine treatment in Highper mice and is maintained throughout conditioning but may be limited by a ceiling effect due to the small CPP chamber size. In B6 mice, a gradual increase in locomotor response occurs across all 4 days of cocaine administration. We previously reported that CPP chamber characteristics are critical in the expression of cocaine sensitization in BALB/cByJ (Eisener-Dorman et al. 2011), and increased sensitization to psychostimulants has been observed in rats when drugs are administered in novel rather than home environments; therefore, sensitization may be increased in environments associated with greater activity. The causes of context-specific sensitization are not yet clear, but the HPA axis and dopamine neurotransmission have been implicated (Badiani et al. 1995; Goeders 2002a; Williams and Adinoff 2008).

The primary finding in the cocaine self-administration study was increased responding by Highper mice for cocaine at the lowest doses tested with no overall strain differences in inactive lever responding, progressive ratio responding, or responding during extinction. Importantly, all mice showed an increase in lever pressing in the initial extinction trials, suggesting that they were indeed lever pressing for reward and not simply falling into habitual lever pressing behavior. When the sexes were analyzed separately, female Highper mice had higher progressive ratio breakpoints than female B6 mice, and male Highper mice had higher active lever presses during extinction than male B6 mice. It should be noted that a dose effect curve was not observed in either B6 or Highper mice during PR tests. While PR dose effect curves are consistently observed in rats, they can be more difficult to capture in mice. In fact, it is more common to see single-dose PR tests in the mouse literature. Depending on the background strain and the specific methods used (acquisition protocol, dose order, intervening day treatment), dose effect curves, albeit not necessarily inverted U-shaped ones, have been observed using a between-subjects design or when the lowest dose is tested last (Alsio et al. 2011; Schmidt et al. 2011; Sorensen et al. 2012). However, under other experimental conditions, dose effect curves have not been observed (Ozburn et al. 2012).

Considered together, the self-administration and place preference data are consistent with the hypothesis that Highper mice are more sensitive to the rewarding effects of cocaine. However, it should be noted that the place preference assay was only performed with a single dose of cocaine and, therefore, is not generalizable over a wider dose range.

Highper mice subjected to acute restraint stress exhibit a prolonged HPA response similar to that of HR rats. The HPA axis has previously been implicated in cocaine behaviors
(Piazza and Le Moal 1998). Acute cocaine administration increases circulating CORT levels (Borowsky and Kuhn 1991; Levy et al. 1991; Mello and Mendelson 1997), which increases sensitivity to lower doses of cocaine (Goeders 2002a, b; Goeders and Guerin 1994; Mantsch et al. 1998). Adrenalectomy reduces the psychomotor properties of cocaine, and supplementation of CORT to basal levels reverses the effect (Marinelli et al. 1994). In addition, stressors enhance the acquisition of self-administration (Goeders 2002b; Piazza and Le Moal 1998). These data lead to the hypothesis that increased HPA reactivity renders Highper mice more sensitive to the activating effects of psychostimulants. However, Highper mice do not differ in basal CORT or in circulating CORT following cocaine exposure in the open field, so HPA activation during open-field testing does not explain their locomotor response to cocaine.

The HPA axis also interacts with mesolimbic dopaminergic neurons in brain regions that have been implicated in drug reward (Piazza and Le Moal 1996, 1998). Glucocorticoid hormones increase dopamine release in the nucleus accumbens and sensitivity to the psychomotor effects of psychostimulants (Marinelli et al. 1994). Highper and B6 mice may differ in some aspect of the mesolimbic dopaminergic system, and further studies are warranted. Early life stressors, including prenatal stress and deficits in maternal care, are also implicated in increased sensitivity to psychostimulants (Kippin et al. 2008; Li et al. 2003), and we cannot eliminate the possibility that Highper mothers experience higher HPA activity during gestation or differ in the maternal care provided to their offspring.

A mutation affecting the dopaminergic pathway is a plausible explanation for the observed phenotypes given that Highper mice show increased locomotor activity, exaggerated locomotor responses to both cocaine and ethanol, and increased sensitivity to the rewarding and reinforcing effects of cocaine - all behaviors that are mediated by the mesolimbic dopamine and the brain reward pathways. Interestingly, cocaine- and ethanol-induced locomotor activations are genetically related in ethanol FAST and SLOW lines selectively bred for sensitivity to ethanol (Meyer et al. 2009). Injection of both cocaine and ethanol results in greater levels of dopamine in the nucleus accumbens of FAST mice (Meyer et al. 2009). The quantification of brain dopamine levels in Highper mice during open-field testing and in response to psychostimulant administration is the next logical step in determining if increased dopamine is related to the locomotor and drug-related behaviors.

The identification of the causative gene is a crucial step towards understanding the spectrum of Highper mutant phenotypes. Previous gene mapping efforts for ENU behavioral mutants have been slowed by limitations in the tools available for gene identification. However, recent advances in SNP discovery and the emergence of accessible sequencing 
technology provide the tools necessary to identify ENUinduced mutations. Phenotypic characterization of mouse models of cocaine-induced locomotor activation, such as the Highper mutant, will expand the existing knowledge of the neurobiological pathways driving initial sensitivity to cocaine. Consequently, identification of the causative mutation in Highper will lead to the discovery of genes or gene pathways that may influence individual susceptibility to addiction.

Acknowledgments This research was supported by funding from NIH NIDA Grant DA022392 and DA023690 to L.M.T., a Novartis Grant SFP-1406 from the Genomics Institute of the Novartis Research Foundation, and NIH Blueprint Core Grant NS057096.

Conflict of interest The authors declare no conflicts of interest.

Open Access This article is distributed under the terms of the Creative Commons Attribution License which permits any use, distribution, and reproduction in any medium, provided the original author(s) and the source are credited.

\section{References}

Alsio J, Nordenankar K, Arvidsson E, Birgner C, Mahmoudi S, Halbout B, Smith C, Fortin GM, Olson L, Descarries L, Trudeau LE, Kullander K, Levesque D, Wallen-Mackenzie A (2011) Enhanced sucrose and cocaine self-administration and cue-induced drug seeking after loss of VGLUT2 in midbrain dopamine neurons in mice. $\mathrm{J}$ Neurosci 31:12593-12603

Badiani A, Anagnostaras SG, Robinson TE (1995) The development of sensitization to the psychomotor stimulant effects of amphetamine is enhanced in a novel environment. Psychopharmacology (Berl) 117:443-452

Belin D, Berson N, Balado E, Piazza PV, Deroche-Gamonet V (2011) High-novelty-preference rats are predisposed to compulsive cocaine self-administration. Neuropsychopharmacology 36:569579

Bierut LJ, Dinwiddie SH, Begleiter H, Crowe RR, Hesselbrock V, Nurnberger JI Jr, Porjesz B, Schuckit MA, Reich T (1998) Familial transmission of substance dependence: alcohol, marijuana, cocaine, and habitual smoking: a report from the Collaborative Study on the Genetics of Alcoholism. Arch Gen Psychiatry 55:982-988

Borowsky B, Kuhn CM (1991) Monoamine mediation of cocaineinduced hypothalamo-pituitary-adrenal activation. J Pharmacol Exp Ther 256:204-210

Bowers SL, Bilbo SD, Dhabhar FS, Nelson RJ (2008) Stressor-specific alterations in corticosterone and immune responses in mice. Brain Behav Immun 22:105-113

Boyle AE, Gill K (2001) Sensitivity of AXB/BXA recombinant inbred lines of mice to the locomotor activating effects of cocaine: a quantitative trait loci analysis. Pharmacogenetics 11:255-264

Brabant C, Quertemont E, Tirelli E (2005) Evidence that the relations between novelty-induced activity, locomotor stimulation and place preference induced by cocaine qualitatively depend upon the dose: a multiple regression analysis in inbred C57BL/6J mice. Behav Brain Res 158:201-210

Bryant CD, Parker CC, Zhou L, Olker C, Chandrasekaran RY, Wager TT, Bolivar VJ, Loudon AS, Vitaterna MH, Turek FW, Palmer AA (2012) Csnk1e is a genetic regulator of sensitivity to psychostimulants and opioids. Neuropsychopharmacology 37 (4):1026-1035

Crabbe JC, Belknap JK, Buck KJ (1994) Genetic animal models of alcohol and drug abuse. Science 264:1715-1723

Crabbe JC, Phillips TJ, Buck KJ, Cunningham CL, Belknap JK (1999) Identifying genes for alcohol and drug sensitivity: recent progress and future directions. Trends Neurosci 22:173-179

Crawley JN (1999) Behavioral phenotyping of transgenic and knockout mice: experimental design and evaluation of general health, sensory functions, motor abilities, and specific behavioral tests. Brain Res 835:18-26

Cunningham CL, Dickinson SD, Grahame NJ, Okorn DM, McMullin CS (1999) Genetic differences in cocaine-induced conditioned place preference in mice depend on conditioning trial duration. Psychopharmacology (Berl) 146:73-80

Deroche V, Piazza PV, Le Moal M, Simon H (1993) Individual differences in the psychomotor effects of morphine are predicted by reactivity to novelty and influenced by corticosterone secretion. Brain Res 623:341-344

Downing C, Carosone-Link P, Bennett B, Johnson T (2006) QTL mapping for low-dose ethanol activation in the LXS recombinant inbred strains. Alcohol Clin Exp Res 30:1111-1120

Eisener-Dorman AF, Grabowski-Boase L, Tarantino LM (2011) Cocaine locomotor activation, sensitization and place preference in six inbred strains of mice. Behav Brain Funct 7:29

Erb SM, Parker LA (1994) Individual differences in novelty-induced activity do not predict strength of amphetamine-induced place conditioning. Pharmacol Biochem Behav 48:581-586

Frankel WN, Yang Y, Mahaffey CL, Beyer BJ, O’Brien TP (2009) Szt2, a novel gene for seizure threshold in mice. Genes Brain Behav 8:568-576

Furuse T, Wada Y, Hattori K, Yamada I, Kushida T, Shibukawa Y, Masuya H, Kaneda H, Miura I, Seno N, Kanda T, Hirose R, Toki S, Nakanishi K, Kobayashi K, Sezutsu H, Gondo Y, Noda T, Yuasa S, Wakana S (2010) Phenotypic characterization of a new Grin1 mutant mouse generated by ENU mutagenesis. Eur J Neurosci 31:1281-1291

George FR, Goldberg SR (1989) Genetic approaches to the analysis of addiction processes. Trends Pharmacol Sci 10:78-83

Goeders NE (2002a) Stress and cocaine addiction. J Pharmacol Exp Ther 301:785-789

Goeders NE (2002b) The HPA axis and cocaine reinforcement. Psychoneuroendocrinology 27:13-33

Goeders NE, Guerin GF (1994) Non-contingent electric footshock facilitates the acquisition of intravenous cocaine selfadministration in rats. Psychopharmacology (Berl) 114:63-70

Gong W, Neill DB, Justice JB Jr (1996) Locomotor response to novelty does not predict cocaine place preference conditioning in rats. Pharmacol Biochem Behav 53:191-196

Gremel CM, Cunningham CL (2007) Role of test activity in ethanolinduced disruption of place preference expression in mice. Psychopharmacology (Berl) 191:195-202

Grillet N, Schwander M, Hildebrand MS, Sczaniecka A, Kolatkar A, Velasco J, Webster JA, Kahrizi K, Najmabadi H, Kimberling WJ, Stephan D, Bahlo M, Wiltshire T, Tarantino LM, Kuhn P, Smith RJ, Muller U (2009) Mutations in LOXHD1, an evolutionarily conserved stereociliary protein, disrupt hair cell function in mice and cause progressive hearing loss in humans. Am J Hum Genet 85:328-337

Keays DA, Nolan PM, Oliver P, Tian G, Fullerton J, Rees M, Harvey RJ, Cowan NJ, Davies KE, Flint J (2004) Jenna: a novel ENU hyperactive mouse mutant with an enhanced acoustic startle response 18th International Mouse Genome Conference, Seattle, WA

Kippin TE, Szumlinski KK, Kapasova Z, Rezner B, See RE (2008) Prenatal stress enhances responsiveness to cocaine. Neuropsychopharmacology 33:769-782 
Kiyatkin EA (1992) State-dependent peculiarities of cocaine-induced behavioral sensitization and their possible reasons. Int J Neurosci 67:93-103

Kosten TA, Zhang XY, Haile CN (2007) Strain differences in maintenance of cocaine self-administration and their relationship to novelty activity responses. Behav Neurosci 121:380-388

Levy AD, Li QA, Kerr JE, Rittenhouse PA, Milonas G, Cabrera TM, Battaglia G, Alvarez Sanz MC, Van de Kar LD (1991) Cocaineinduced elevation of plasma adrenocorticotropin hormone and corticosterone is mediated by serotonergic neurons. $\mathrm{J}$ Pharmacol Exp Ther 259:495-500

Li Y, Robinson TE, Bhatnagar S (2003) Effects of maternal separation on behavioural sensitization produced by repeated cocaine administration in adulthood. Brain Res 960:42-47

Mackenzie FE, Parker A, Parkinson NJ, Oliver PL, Brooker D, Underhill P, Lukashkina VA, Lukashkin AN, Holmes C, Brown SD (2009) Analysis of the mouse mutant Cloth-ears shows a role for the voltage-gated sodium channel Scn8a in peripheral neural hearing loss. Genes Brain Behav 8:699-713

Mantsch JR, Saphier D, Goeders NE (1998) Corticosterone facilitates the acquisition of cocaine self-administration in rats: opposite effects of the type II glucocorticoid receptor agonist dexamethasone. J Pharmacol Exp Ther 287:72-80

Marinelli M, Piazza PV, Deroche V, Maccari S, Le Moal M, Simon H (1994) Corticosterone circadian secretion differentially facilitates dopamine-mediated psychomotor effect of cocaine and morphine. J Neurosci 14:2724-2731

Mello NK, Mendelson JH (1997) Cocaine's effects on neuroendocrine systems: clinical and preclinical studies. Pharmacol Biochem Behav 57:571-599

Meyer PJ, Meshul CK, Phillips TJ (2009) Ethanol- and cocaineinduced locomotion are genetically related to increases in accumbal dopamine. Genes Brain Behav 8:346-355

Neisewander JL, Pierce RC, Bardo MT (1990) Naloxone enhances the expression of morphine-induced conditioned place preference. Psychopharmacology (Berl) 100:201-205

Ozburn AR, Larson EB, Self DW, McClung CA (2012) Cocaine selfadministration behaviors in ClockDelta19 mice. Psychopharmacology (Berl) (in press)

Pañeda C, Huitron-Resendiz S, Frago LM, Chowen JA, Picetti R, de Lecea L, Roberts AJ (2009) Neuropeptide S reinstates cocaineseeking behavior and increases locomotor activity through corticotropin-releasing factor receptor 1 in mice. J Neuroscience 29 (13):4155-4161

Parker A, Hardisty-Hughes RE, Wisby L, Joyce S, Brown SD (2010) Melody, an ENU mutation in Caspase 3, alters the catalytic cysteine residue and causes sensorineural hearing loss in mice. Mamm Genome 21:565-576

Piazza PV, Le Moal ML (1996) Pathophysiological basis of vulnerability to drug abuse: role of an interaction between stress, glucocorticoids, and dopaminergic neurons. Annu Rev Pharmacol Toxicol 36:359-378

Piazza PV, Le Moal M (1998) The role of stress in drug selfadministration. Trends Pharmacol Sci 19:67-74

Piazza PV, Deminiere JM, Le Moal M, Simon H (1989) Factors that predict individual vulnerability to amphetamine self-administration. Science 245:1511-1513

Piazza PV, Deminiere JM, Maccari S, Mormede P, Le Moal M, Simon $H$ (1990) Individual reactivity to novelty predicts probability of amphetamine self-administration. Behav Pharmacol 1:339-345

Piazza PV, Maccari S, Deminiere JM, Le Moal M, Mormede P, Simon H (1991) Corticosterone levels determine individual vulnerability to amphetamine self-administration. Proc Natl Acad Sci U S A 88:2088-2092

Reijmers LG, Coats JK, Pletcher MT, Wiltshire T, Tarantino LM, Mayford M (2006) A mutant mouse with a highly specific contextual fear-conditioning deficit found in an N-ethyl-N-nitrosourea (ENU) mutagenesis screen. Learn Mem 13:143-149

Ruiz-Durantez E, Hall SK, Steffen C, Self DW (2006) Enhanced acquisition of cocaine self-administration by increasing percentages of C57BL/6J genes in mice with a nonpreferring outbred background. Psychopharmacology (Berl) 186:553-560

Schmidt LS, Thomsen M, Weikop P, Dencker D, Wess J, Woldbye DP, Wortwein G, Fink-Jensen A (2011) Increased cocaine selfadministration in M4 muscarinic acetylcholine receptor knockout mice. Psychopharmacology (Berl) 216:367-378

Schwander M, Lopes V, Sczaniecka A, Gibbs D, Lillo C, Delano D, Tarantino LM, Wiltshire T, Williams DS, Muller U (2009a) A novel allele of myosin VIIa reveals a critical function for the Cterminal FERM domain for melanosome transport in retinal pigment epithelial cells. J Neurosci 29:15810-15818

Schwander M, Xiong W, Tokita J, Lelli A, Elledge HM, Kazmierczak P, Sczaniecka A, Kolatkar A, Wiltshire T, Kuhn P, Holt JR, Kachar B, Tarantino L, Muller U (2009b) A mouse model for nonsyndromic deafness (DFNB12) links hearing loss to defects in tip links of mechanosensory hair cells. Proc Natl Acad Sci U S A 106:5252-5257

Seale TW, Carney JM (1991) Genetic determinants of susceptibility to the rewarding and other behavioral actions of cocaine. J Addict Dis 10:141-162

Sharkey LM, Cheng X, Drews V, Buchner DA, Jones JM, Justice MJ, Waxman SG, Dib-Hajj SD, Meisler MH (2009) The ataxia3 mutation in the $\mathrm{N}$-terminal cytoplasmic domain of sodium channel $\mathrm{Na}$ (v)1.6 disrupts intracellular trafficking. J Neurosci 29:2733-2741

Shimosato K, Watanabe S (2003) Concurrent evaluation of locomotor response to novelty and propensity toward cocaine conditioned place preference in mice. J Neurosci Methods 128:103-110

Sora I, Hall FS, Andrews AM, Itokawa M, Li XF, Wei HB, Wichems C, Lesch KP, Murphy DL, Uhl GR (2001) Molecular mechanisms of cocaine reward: combined dopamine and serotonin transporter knockouts eliminate cocaine place preference. Proc Natl Acad Sci USA 98:5300-5305

Sorensen G, Jensen M, Weikop P, Dencker D, Christiansen SH, Loland CJ, Bengtsen $\mathrm{CH}$, Petersen JH, Fink-Jensen A, Wortwein G, Woldbye DP (2012) Neuropeptide Y Y5 receptor antagonism attenuates cocaine-induced effects in mice. Psychopharmacology (Berl) 222(4):565-577

Speca DJ, Chihara D, Ashique AM, Bowers MS, Pierce-Shimomura JT, Lee J, Rabbee N, Speed TP, Gularte RJ, Chitwood J, Medrano JF, Liao M, Sonner JM, Eger EI, 2nd, Peterson AS, McIntire SL (2010) Conserved role of unc-79 in ethanol responses in lightweight mutant mice. PLoS Genet 6(8). pii: e1001057

Swanson DJ, Steshina EY, Wakenight P, Aldinger KA, Goldowitz D, Millen KJ, Chizhikov VV (2010) Phenotypic and genetic analysis of the cerebellar mutant tmgc26, a new ENU-induced ROR-alpha allele. Eur J Neurosci 32:707-716

Thomsen M, Caine SB (2011) Psychomotor stimulant effects of cocaine in rats and 15 mouse strains. Exp Clin Psychopharmacol 19:321-341

Tokuda S, Mahaffey CL, Monks B, Faulkner CR, Birnbaum MJ, Danzer SC, Frankel WN (2011) A novel Akt3 mutation associated with enhanced kinase activity and seizure susceptibility in mice. Hum Mol Genet 20(5):988-999

Uhl GR, Elmer GI, LaBuda MC, Pickens RW (1995) Genetic influences in drug abuse. In: Bloom FE, Kupfer DJ (eds) Psychopharmacology: the fourth generation of progress. Raven, New York, pp 1793-1806

Vezina P, Stewart J (1987) Morphine conditioned place preference and locomotion: the effect of confinement during training. Psychopharmacology (Berl) 93:257-260

Williams MJ, Adinoff B (2008) The role of acetylcholine in cocaine addiction. Neuropsychopharmacology 33:1779-1797

Xie G, Harrison J, Clapcote SJ, Huang Y, Zhang JY, Wang LY, Roder JC (2010) A new Kv1.2 channelopathy underlying cerebellar ataxia. J Biol Chem 285:32160-32173 